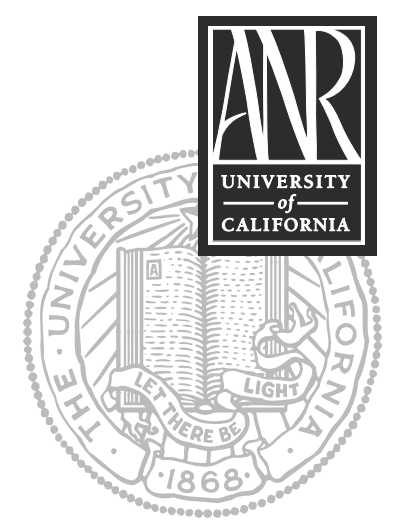

UNIVERSITY OF CALIFORNIA

Division of Agriculture and Natural Resources http://anrcatalog.ucdavis.edu

\title{
Minimum Tillage Vegetable Crop Production in California
}

JEFFREY MITCHELL, Cropping Systems Specialist, Department of Plant Science, University of California, Davis; LOUISE JACKSON, Professor and Specialist, Department of Soils and Biogeochemistry, University of California, Davis; GENE MIYAO, University of California Cooperative Extension Farm Advisor, Yolo, Solano, and Sacramento Counties

California vegetable production is a high-value and high-risk business due to its special production and marketing requirements. A key to profitability is the delivery of produce into precise time slots in an often volatile market. Customarily, vegetable production systems include intensive tillage and soil preparation to establish level, highly uniform soil conditions. Tillage operations in vegetable production typically represent considerable time, energy, equipment, and labor costs that often comprise more than 25 percent of overall preharvest production budgets. In an effort to control costs and optimize soil management, a wide range of reduced-tillage, or minimumtillage, production systems for vegetables have recently been developed. This publication reviews the major attributes of minimum tillage and current examples of its use in vegetable cropping systems in the San Joaquin and Salinas Valleys of California.

\section{FUNCTIONS OF TILLAGE}

Tillage, the mechanical manipulation of soil to provide suitable conditions for crop growth and development (Koller 2003), may be required for any of a number of reasons (Carter 1996):

- to create a seedbed

- to loosen compacted soil layers

- for weed, insect, and pathogen control

- for aeration

- to incorporate crop and weed residues into the soil

- to inject or incorporate fertilizers and pesticides

- to facilitate irrigation, water infiltration, and soil moisture storage

- to stimulate net nitrogen mineralization

Carter (1996) noted that tradition and aesthetics determined to a large extent the type of tillage historically used in a given production system. The straightness of one's rows and the degree to which one achieved residue-free fallow conditions between crops were considered to be worthwhile objectives that would enhance productivity. As more types of tillage implements have become available and as farmers face increased fuel, labor, and equipment costs, more options for tillage and soil management are being considered.

Soil and environmental factors have also contributed to the goal of reducing tillage. While moderate tillage may provide more favorable soil conditions for crop growth and development over the short term, (i.e., weeks to months), intensive tillage of agricultural soils has historically resulted in severe soil erosion (Larson and Osborne 1982), substantial loss of soil carbon ranging from 30 to 50 percent (Schlesinger 1985), and considerable respirable dust emissions (Baker et al. 2002). Soil organic nitrogen is more readily mineralized after tillage and can be lost during subsequent irrigation or if crops are absent or have low nitrogen demand (Silgram 
and Shepherd 1999). Tillage disrupts soil aggregates, exposing more organic matter to microbial degradation and oxidation (Reicosky et al. 1997), which is one of the primary causes of tilth deterioration over the long term (Karlen et al. 1990). Micro- and macro-channels within the soil created by natural processes such as decaying roots and earthworm burrows may also be destroyed by tillage (Carter 1996). Soil compaction that may result from repeated tillage operations may require periodic deep tillage to break up dense subsurface layers. Deep tillage, however, may create a rough, blocky surface and can require increased subsequent tillage to prepare seedbeds.

In light of its seemingly major advantages, reducing tillage has become a major public policy objective of agencies such as the USDA Natural Resources Conservation Service and the Soil Science Society of America (Larson and Osborne 1982). However, because the optimal tillage intensity depends on a multitude of factors, there can be no universal recipe or rule for optimal tillage (Carter 1996).

\begin{tabular}{l} 
Table 1. Between-crop tillage operations commonly \\
used in conventional vegetable crop production \\
chopping or shredding crop residues \\
disking $(2-3 \times)$ \\
ripping or subsoiling $14-25$ inches $(36-64 \mathrm{~cm})$ deep \\
disking \\
landplaning \\
\hline listing furrows \\
\hline bed shaping \\
applying preplant fertilizers and pesticides \\
\hline power incorporation or final bed shaping prior to seeding \\
\hline
\end{tabular}

\section{TYPES OF TILLAGE}

Most current vegetable production in California is very tillage-intensive. Tillage is typically done in a "broadcast" manner throughout a field without regard to preserving dedicated crop growth or traffic zones. Depending on the particular crop rotation in question, standard land preparation operations that occur between successive crops may include the generalized tillage operations listed in table 1.

Based on information collected from formal and informal surveys of row crop growers, a very wide range of variants of this basic set of operations can be found.

\section{MINIMUM TILLAGE}

In the 1990s, a number of reduced-tillage or minimum-tillage alternatives were developed and successfully used to produce a wide range of vegetable crops in the Central and Salinas Valleys. Development of these systems has been stimulated primarily by the desire to reduce production costs and to decrease the time needed for tilling between crops or for incorporating a winter-grown cover crop. Other factors stimulating interest in alternative approaches to tillage include the difficulty of seedbed preparation in fields with subsurface drip irrigation, as well as recognition that the 2002 Farm Bill provides incentive-based opportunities for farmers to voluntarily address environmental resource concerns such as air quality and soil carbon sequestration.

Two main types of minimum tillage have appeared during this period: permanent bed, or zone traffic, systems in which dedicated crop growth zones (beds) are preserved by restricting tractor traffic to designated lanes (furrows); and systems that rely on reduced-pass, all-in-one tillage implements that prepare seedbeds with fewer operations than are used in standard tillage.

To accomplish more operations with fewer tractor passes, some minimum-tillage equipment accomplishes multiple tillage functions in one pass. Typical minimum-tillage implements consist of a heavy-duty support frame with various combinations of shanks, coulters, disks, sweeps, and bed-forming hoods or shrouds that attach to a tractor by either a 3-point or tongue hitch. A minimum-tillage implement may weigh more than any single implement used in a standard tillage program, yet growers report less horsepower used per acre with minimum-tillage practices than with conventional tillage. 


\section{MINIMUM TILLAGE IN THE SAN JOAQUIN VALLEY}

The San Joaquin Valley's West Side is one of California's major vegetable production regions. Tomatoes, melons, onions, garlic, and broccoli are produced in rotation with other row crops including cotton, corn, and field crops such as wheat and barley. Two different but complementary minimum-tillage approaches have recently been developed by West Side farmers to meet the particular needs of their production systems. In rotations that primarily use 60-inch $(1.5-\mathrm{m})$ beds (tomatoes, cotton, wheat) and that frequently have buried drip irrigation systems, minimum-tillage implements are used that permit semipermanent bed, or dedicated traffic zone, production. In these systems, beds may be preserved over a number of crop cycles. In rotations in which bed width varies from crop to crop (onions, garlic, tomatoes, cotton), tillage implements are used that enable reduced-pass seedbed preparation tillage but do not preserve beds. Global positioning system (GPS) guidance technologies have facilitated this system by allowing the precise reestablishment of beds and furrows. A wide variety of minimum-tillage approaches are currently being applied in West Side rotations using these two systems.

\section{Permanent-Bed Systems}

The standard 2-year rotation of wheat and processing tomatoes in the West Side region follow an intercrop tillage program similar to the one outlined in table 1 . Recently, a much-abbreviated tillage sequence following the wheat harvest has been used successfully before establishing processing tomatoes. In this system, a preirrigation is applied in September to replenish the soil moisture profile in the nontilled wheat stubble. Once the soil surface has dried, two passes with a permanent-bed minimum-tillage implement are made to shallowly mix wheat residues with surface soil. A final pass is made in October

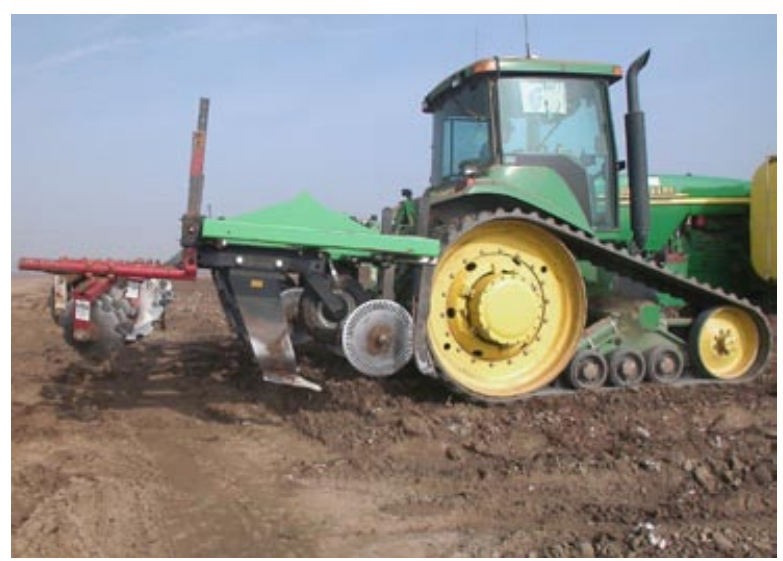

Figure 1. Terratill bent leg subsoiling shank implement (Bigham Brothers, Lubbock, Texas) used to loosen soil profile following crop harvest.

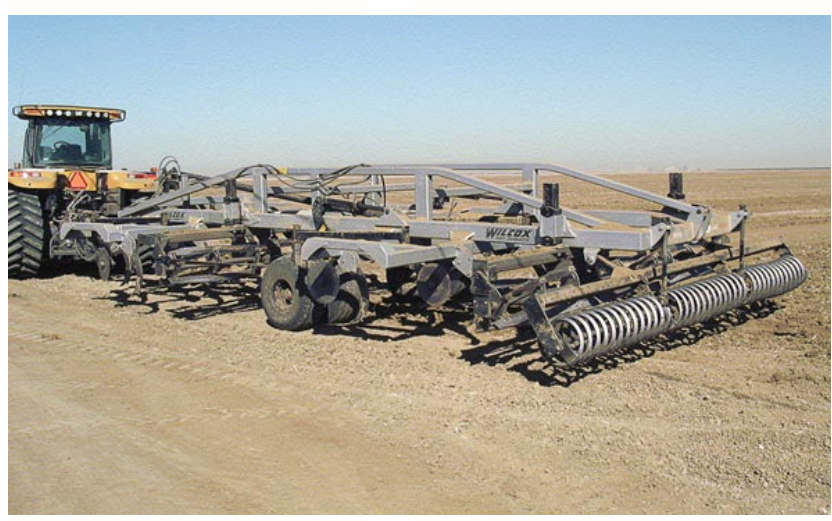

Figure 2. Wilcox Brothers (Walnut Grove, California) Eliminator implement for minimum tillage following harvest. to apply and incorporate phosphorus fertilizer using a grounddriven spiked rotary harrow or a Lilliston-type implement. The latter implement also serves as a refining tool to condition planting beds for the subsequent tomato crop.

Another type of semipermanent-bed minimum-tillage program implemented by West Side producers uses a bent leg subsoiling shank that lifts and loosens soil in the plant row while maintaining firm traffic lanes in furrows (fig. 1). This implement enables zone production following tomatoes and preceding cotton, converting from 60 -inch $(1.5-\mathrm{m})$ to 30 -inch $(75-\mathrm{cm})$ centered beds. In this system, following tomato harvest, two light diskings precede the bent leg shank implement. Grower experience shows that multiple operations (chiseling, listing, and injecting fertilizer) may be accomplished in one pass. Since no wheel traffic occurs over the plant line, soil compaction is reduced relative to typical broadcast tillage and soil preparation programs. Implementation of this type of system has also been greatly facilitated by the use of GPS guidance technology.

\section{All-In-One Systems}

All-in-one tillage implements that combine several tillage functions into one pass have also been used recently in West Side row crop fields. Two passes at $45^{\circ}$ cross-angles with one of these implements prior to listing beds is a minimum-tillage sequence that has been used following crops such as lettuce, corn, wheat, spinach, and cotton (fig. 2). Subsoiling to loosen the soil profile and landplaning to smooth the soil surface are added to this reduced tillage before planting tomatoes. 


\section{MINIMUM TILLAGE IN THE SALINAS VALLEY}

The Salinas Valley is one of the nation's major production regions for cool-season vegetables such as lettuce, broccoli, cauliflower, and celery. Usually, two cool-season vegetable crops are grown per year, leaving insufficient time for rotation with other crops. Winter nonleguminous cover crops, however, are increasingly being used. The minimum-tillage approaches that are used by farmers in this region are variants of the permanent-bed systems that have been described above. Growers maintain beds for a few months to a few years. Minimum tillage may be used solely between summer vegetable crops as a way to quickly transition from harvesting one crop to seeding the second crop. Alternatively, beds may remain in place for several years (e.g., when subsurface drip irrigation is used), in order to avoid disturbing the drip tape that is buried 6 to 10 inches ( 15 to $25 \mathrm{~cm}$ ) below the soil surface. While drip irrigation is less widely used than sprinkler and furrow irrigation, surface drip has now become more popular than subsurface drip irrigation. Surface drip allows more tillage options between crops since the tape can be removed and replaced more easily than subsurface drip tape.

Tillage differs between the Salinas Valley and the San Joaquin Valley. In the Salinas Valley, ripping and subsoiling is usually done only after the harvest of the second vegetable crop in the fall. Another difference is that in the Salinas Valley, incorporation of residues of many crops, especially lettuce and spinach, can be accomplished more easily with minimum-tillage equipment because the unharvested plant material is usually not abundant, and it decomposes fairly rapidly due to its high water con-

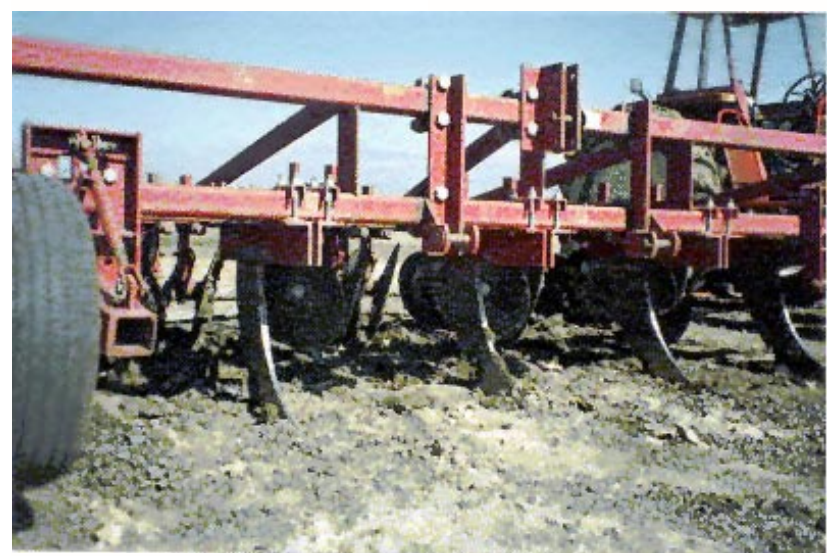

Figure 3. Close-up view of Sundance minimum-tillage bed-conditioning implement used in the Salinas Valley.

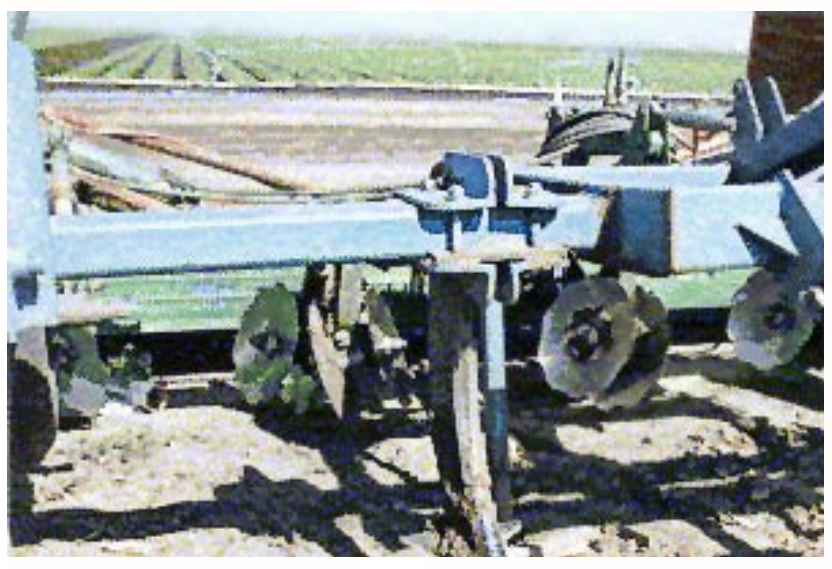

Figure 4. Minimum-tillage chisel for use in the Salinas Valley on permanent beds to simultaneously disk-hill the beds and chisel the furrows to approximately 20 inches $(50 \mathrm{~cm})$ deep with a narrow shank. tent and low carbon-to-nitrogen ratio. Winter cover crops in the Salinas Valley often grow for less than 3 months and can be successfully incorporated using minimum tillage. Otherwise, operations are similar to those described for the San Joaquin Valley.

\section{Sundance System}

The most common minimum-tillage operation in the Salinas Valley is shallow minimum tillage using a Sundance system (from Sundance Farms, Coolidge, Arizona) (fig. 3), followed by a Lilliston-type implement, rollers, and bed-shapers. The Sundance system uses disks and lister bottoms to incorporate crop residues and cultivate the tops and sides of the beds in a single pass. This method is generally used to till approximately 8 inches (20 cm) deep, but it can be adjusted for depth.

Deeper minimum tillage increases the intensity and depth of the cultivation of the soil yet retains traffic-free beds, often over several years. A comprehensive system has been developed by American Farms in Chualar, California, that tills the soil to approximately 20 inches $(50 \mathrm{~cm})$ deep. It consists of four tillage operations, with one pass per implement. First, a minimum-till chisel simultaneously uses a narrow shank to loosen the soil in the furrows to a depth of approximately 20 inches $(50 \mathrm{~cm})$, while a disk hiller forms peaked beds (fig. 4). This is followed by using the Sundance system to mix the soil and break large clods. A minimum-till ripper then uses broad, angled shanks with floating wings to break the compacted layer across the beds to a depth of approximately 20 inches $(50 \mathrm{~cm})$ 


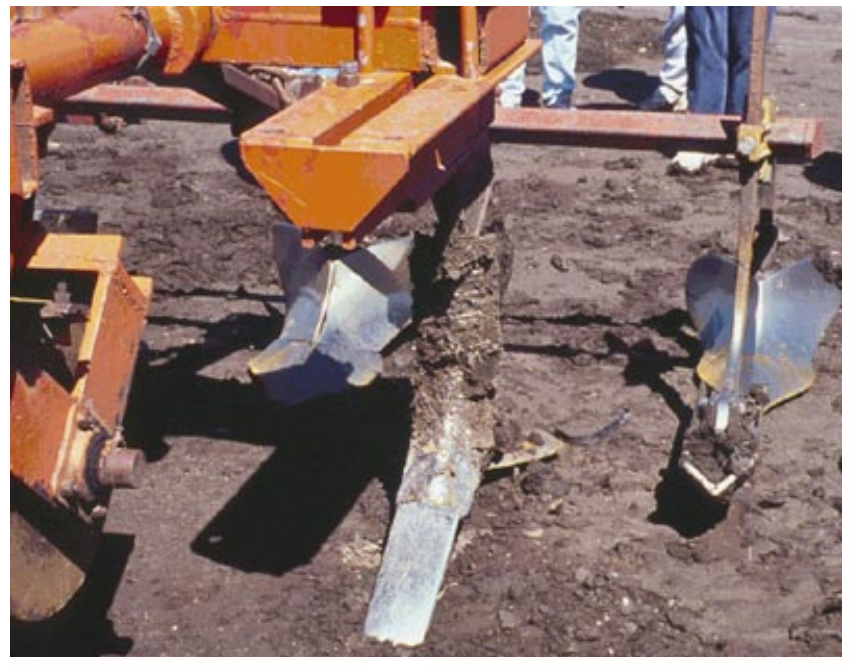

Figure 5. Minimum-tillage ripper for use in the Salinas Valley on permanent beds to break compacted layers to approximately 20 inches $(50 \mathrm{~cm})$ deep with angled, broad shanks and floating wings.

(fig. 5). Finally, a surface rototiller-mulcher smoothes the surface and prepares the seedbed. This four-step method is completed in 1.5 to 2 tractor hours per acre (3.5 to $5 \mathrm{hr} / \mathrm{ha}$ ).

\section{Comparisons of Tillage Systems in the Salinas Valley}

Various tillage methods have been compared in on-farm trials in the Salinas Valley for their effects on soil properties, soil microbiological parameters, yield, weeds, pests, and economics. Minimum tillage has been used for over 10 years in the Salinas Valley, and researchers have been able to conduct 2- and 3-year on-farm experiments.

\section{Shallow Minimum Tillage versus Conventional Tillage}

A multidisciplinary study compared shallow minimum tillage with conventional tillage for 2 years on a 20 -acre (8-ha) field of silt loam soil in the Salinas Valley (Jackson et al. 2004). Minimum tillage with the Sundance system retained permanent beds over the 2-year study, with tillage confined to the surface 8 inches $(20 \mathrm{~cm})$. Conventional tillage used more passes, including a subsoiling to a depth of 20 inches $(50 \mathrm{~cm})$. No cover crops or compost were used. All other management practices were similar between the two systems.

Tillage practices had generally similar effects on soils except that $\mathrm{NO}_{3}{ }^{-}-\mathrm{N}$ in the deep profile, 0 to 36 inches $(90 \mathrm{~cm}$ ) deep, was consistently lower with minimum tillage (table 2). Also, gravimetric soil moisture was typically 1 to 2 percent lower in the soil surface layer, 0 to 6 inches $(15 \mathrm{~cm})$ deep, with minimum tillage. There was no difference in bulk density between the tillage treatments at 0 to 2.5 inches $(6 \mathrm{~cm})$ or lower (18 to 20.5 inches, or 46 to $52 \mathrm{~cm}$ ) depths, or in total soil carbon or nitrogen in the surface 6 inches $(15 \mathrm{~cm})$. Soil microbial biomass carbon, a measure of active soil carbon, at 0 to 6 inches $(15 \mathrm{~cm})$ deep was similar throughout the 2-year study until the last sampling date, when it was significantly higher with minimum tillage, probably because accumulation of crop residues in the surface gradually led to more available carbon for microbes.

Minimum tillage tended to decrease fresh lettuce yields compared with conventional tillage by approximately 5 percent (table 3 ). This may have been due to slightly lower moisture in the surface layer and lower nitrogen and phosphorus availability, based on leaf tissue concentrations of these nutrients. No differences in weed, disease,

Table 2. Soil nitrate-nitrogen in the soil profile (means \pm standard error of the mean) at 0-36 inches $(90 \mathrm{~cm})$ deep for a 2-year Salinas Valley on-farm trial comparing continuous minimum tillage on permanent beds using a Sundance system with conventional tillage using disking between crops and subsoiling and disking

\begin{tabular}{|l|c|c|}
\hline & \multicolumn{1}{c|}{$\begin{array}{c}\text { Minimum tillage } \\
\text { Conventional tillage }\end{array}$} \\
\hline July 1998 & \multicolumn{2}{|c|}{ NO $^{-}-\mathrm{N} \mathrm{lb}$ /acre } \\
\hline September 1998 & $216 \pm 18$ & $287 \pm 36$ \\
\hline February 1999 & $329 \pm 16$ & $377 \pm 13$ \\
\hline May 1999 & $546 \pm 15$ & $569 \pm 26$ \\
\hline August 1999 & $254 \pm 23$ & $315 \pm 15$ \\
\hline November 1999 & $124 \pm 14$ & $203 \pm 22$ \\
\hline April 2000 & $433 \pm 31$ & $514 \pm 24$ \\
\hline
\end{tabular}

Source: Jackson et al. 2004. or insect pest problems occurred between the two tillage systems. Economically, minimum tillage had higher net financial returns for two of the three lettuce crops due to lower labor, equipment, and fuel costs than conventional tillage, despite lower yields (see table 3). Minimum tillage was also beneficial in improving some attributes of soil quality, including lower nitrate leaching potential, which may be due to lower net mineralization of soil organic nitrogen below the 6-inch (15-cm) depth, as well as a slight and delayed increase in microbial biomass, which may indicate a slow, gradual increase in soil organic matter in the surface layer. 
Table 3. Lettuce fresh weight yield (mean \pm standard error of the mean) and economic analysis for Salinas Valley on-farm trial described in table 2

\begin{tabular}{|l|c|c|c|c|c|c|c|}
\hline & \multicolumn{2}{|c|}{ July 1998} & \multicolumn{3}{c|}{ May 1999 } & \multicolumn{3}{c|}{ August 1999 } \\
\cline { 2 - 8 } & $\begin{array}{c}\text { Minimum } \\
\text { Tillage }\end{array}$ & $\begin{array}{c}\text { Conventional } \\
\text { Tillage }\end{array}$ & $\begin{array}{c}\text { Minimum } \\
\text { Tillage }\end{array}$ & $\begin{array}{c}\text { Conventional } \\
\text { Tillage }\end{array}$ & $\begin{array}{c}\text { Minimum } \\
\text { Tillage }\end{array}$ & $\begin{array}{c}\text { Conventional } \\
\text { Tillage }\end{array}$ \\
\hline Lettuce yield (g fresh weight/plant) & $1,053 \pm 20$ & $1,106 \pm 26$ & $784 \pm 20$ & $799 \pm 24$ & $1,025 \pm 22$ & $1,096 \pm 20$ \\
\hline Total returns (\$/acre) & 7,894 & 8,297 & 6,304 & 6,431 & 8,643 & 9,188 \\
\hline Total costs (\$acre) & 6,849 & 7,191 & 6,257 & 6,631 & 7,902 & 8,443 \\
\hline Net returns (\$/acre) & 1,045 & 1,105 & 46 & -200 & 741 & 745 \\
\hline Diesel used (gal/acre) & 28 & 61 & 43 & 111 & 22 & 61 \\
\hline
\end{tabular}

Source: Klonsky 1991; Jackson et al. 2004.

Note: A figure of $\$ 7.50$ per lettuce carton was used in the calculation of returns. This was the Monterey County average for the sampling times of the study. Total costs include seed, fertilizer, pesticides, herbicides, custom application, water, land rent, property taxes, insurance, and interest on operating capital, as well as capital recovery cost for equipment and irrigation system ownership using the Budget Planner model.

\section{Shallow versus Deep Minimum Tillage}

A research project on shallow versus deep minimum tillage confirmed that lettuce fresh weight may decrease with 2 and 3 years of continuous use of the Sundance system (Jackson et al. 2002). The study compared the Sundance system, the minimumtill chisel, and the four-step minimum tillage described above (see figs. 3, 4, and 5), on a Cropley silty clay in Chualar, California, in order to determine the effects of different practices for retaining permanent beds.

Lettuce fresh weight was 10 percent lower with the Sundance system compared with deeper minimum tillage on permanent beds that were tilled to approximately 20 inches $(50 \mathrm{~cm})$ depth. Shallow tillage resulted in significantly higher soil microbial biomass carbon in the top 4 inches $(10 \mathrm{~cm})$ of soil compared with deeper tillage for 2 of the 3 years of the study. Few consistent changes in soil properties or water content occurred during the experiment. Of major importance, however, was the finding that symptoms of lettuce drop wilt were significantly higher with shallow minimum tillage ( 4 to 5 percent of the plants) than with deeper minimum tillage (1 to 2 percent of the plants), and there was also a higher incidence of lettuce corky root disease in the shallow minimum tillage in one of the years (56 percent versus 45 percent of the taproots affected). Deeper tillage may bury sclerotia and reduce inoculum. Higher yields with deeper minimum tillage may have been partially attributable to lower disease in this study.

Shallow minimum tillage may be satisfactory for short periods, but to avoid disease problems, it may best be used intermittently with deep minimum tillage or conventional tillage in cool-season vegetable production.

\section{CONSERVATION TILLAGE}

The term "conservation tillage" (CT) has been used recently in California to describe crop production systems that reduce tillage even more than minimum tillage. Most CT systems are based on one of three planting systems that reduce soil disturbance: no-till, ridge-till, and strip-till. In no-till, or zero-till, the only tillage that is used is the soil disturbance in a narrow slot created by coulters or seed openers. The soil surface is generally left undisturbed except at the time of planting. Ridge-till is a reduceddisturbance planting system in which crops are planted and grown on ridges formed during the previous growing season and by shallow, in-season cultivation equipment. Ridge-till planters sweep away or shear off residues and soil in the seed line but do not disturb much of the interrow soil surface. In strip-till, coulters cut residues ahead of subsoiling shanks that loosen the soil from a few to as many as 14 inches $(35 \mathrm{~cm})$ deep ahead of a planter. In each of these CT systems, only a small percentage of the 
soil surface is disturbed, unlike broadcast tillage or land preparation operations that are typically used in conventional tillage.

In addition to reducing soil loss by erosion and runoff, CT has a number of other attributes that have added to its appeal to producers. Because CT aims at reducing primary intercrop tillage operations such as plowing, disking, ripping, and chiseling, fewer tractor operations are used. The consequent reduced fuel use often improves farm profitability. Emissions of dust and various oxides of nitrogen ( $\mathrm{NOx}$ ) may also be reduced, while soil carbon sequestration may be increased. Despite the apparent attractiveness of CT systems, the USDA Natural Resources Conservation Service (NRCS) estimates that less than 1 percent of row crop production acreage in California's Central Valley is currently farmed using CT practices (CTIC 2002).

\section{CT Tomato Production}

In 2002, we conducted two comparisons of CT tomato production alternatives following a wheat crop. One study was conducted in Davis and the other in Parlier, California. Both studies compared three systems: standard-tillage, bed-disk (permanent-bed minimum tillage), and strip-till following a 2000-2001 wheat crop. A Wilcox Performer (Walnut Grove, California) was used as the bed disk-minimum till implement at the Davis site, and a Hahn Bed Disk (Stockton, California) was used at the Parlier location. A 3-row 60-inch Unverferth Ripper Stripper (Kalida, Ohio) was used as the strip-till implement at both sites.

A uniform wheat crop (cv. 'Bonus') was harvested in each of these two fields in July 2001. After harvest of the grain from these fields, tillage and land preparation for the subsequent 2002 tomato crops were done before tomato transplanting in each, as outlined in table 4.

Table 4. Tillage operations for tomatoes following wheat in studies in Davis, CA, and Parlier, CA, 2001-2002

\begin{tabular}{l|l|l|}
\hline Standard tillage & $\begin{array}{l}\text { Bed disk tillage, minimum } \\
\text { (permanent-bed) tillage }\end{array}$ & \multicolumn{1}{c}{ Strip-till } \\
\hline flail chopping & bed disking $(2-3 \times)$ & Strip-tilling \\
\hline stubble disk $(2 \times)$ & & \\
\hline chiselling & & \\
\hline listing & & \\
\hline cultimulch & &
\end{tabular}

Tomatoes (processing tomatoes in Davis and fresh market tomatoes in Parlier) were transplanted in April 2002 using a commercial 3-row rig in Davis and a specially modified reduced-till 3-row SWEMEC transplanter (Woodland, California) developed by our Conservation Tillage Workgroup at the Parlier site. Fertilization, cultivation, and water management were identical among tillage systems at both sites. The entire length of the center row, about 300 feet $(90 \mathrm{~m})$ in Davis and 210 feet $(65 \mathrm{~m})$ in Parlier, of each plot was machine-harvested in Davis and hand-harvested in Parlier at a reasonable fruit maturity stage. Winter weed management prior to the 2002

Table 5. Processing tomato yields in tested tillage systems (means \pm standard error of the mean), Davis, CA, 2002

\begin{tabular}{|c|c|}
\hline Tillage system & Yield (ton/acre) \\
\hline standard tillage & $31 \pm 4.5$ \\
\hline bed disk tillage & $36 \pm 1.3$ \\
\hline strip-till & $35 \pm 3.0$ \\
\hline
\end{tabular}

Table 6. Fresh market tomato yields in tested tillage systems (means \pm standard error of the mean), Parlier, CA, 2002

\begin{tabular}{|c|c|}
\hline Tillage system & Yield (ton/acre) \\
\hline standard tillage & $15 \pm 4$ \\
\hline bed disk tillage & $18 \pm 3$ \\
\hline strip-till & $18 \pm 3$ \\
\hline
\end{tabular}

tomato crops was accomplished at both sites by application of glyphosate herbicide.

Yield data for these studies are presented in tables 5 and 6 . In both studies, establishing tomatoes using a commercial transplanter or a modified conservation tillage transplanter achieved adequate stands even in the minimally tilled strip-till system (fig. 6). Timing of the strip-till operation, however, is critical so that large chunks of dry soil are not brought up, creating very rough bed surfaces that may cause harvest problems, particularly for processing tomatoes. Machine-harvesting the crop at Davis did not create mechanical difficulties or generate additional trash in the harvest. This may have been due to the fact that by the time the tomatoes were harvested in September 2002, the vast majority of the surface residue from the 2001 wheat crop had already been broken down or at least sufficiently worked into the soil to pose minimal mechanical harvester impedance. 


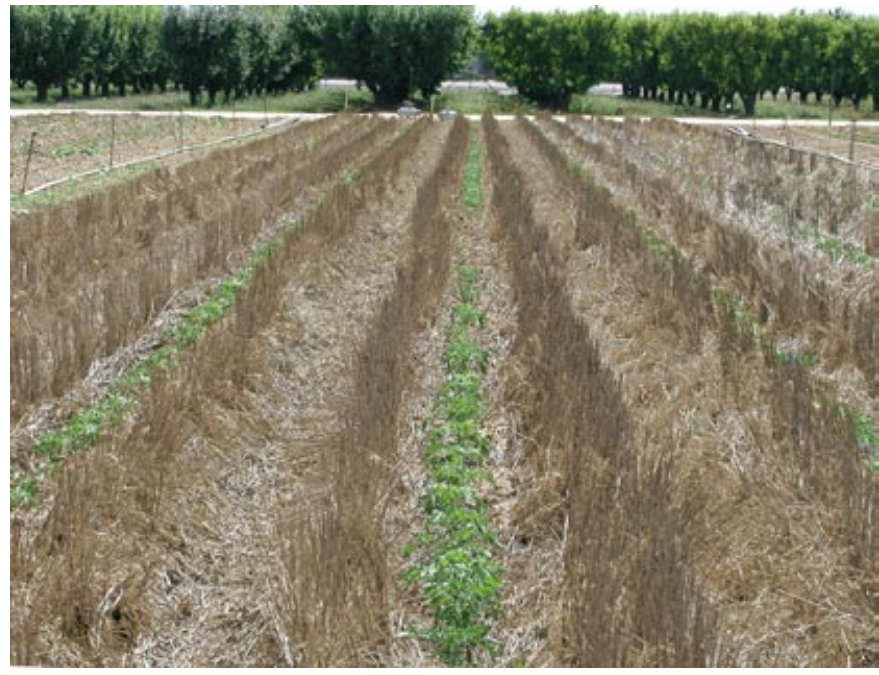

Figure 6. Fresh market tomato plants transplanted into wheat residue, Parlier, California, 2002.

\section{Strip-Till Cantaloupes}

In 1998 and 1999, we compared strip-till melon production using ryegrain-vetch and subclover cover crop mulches with conventional tillage production at the UC West Side Research and Extension Center (WSREC) in Five Points, California. The cover crop mixtures were planted at a seeding rate of 110 pounds per acre $(123.2 \mathrm{~kg} / \mathrm{ha}$ ) for the rye-vetch mix and 30 pounds per acre $(33.6 \mathrm{~kg} / \mathrm{ha})$ for the subclover mix on October 21, 1997, and October 12, 1998, in flat, unlisted field plots. In the conventional-tillage system, 60inch $(1.5-\mathrm{m})$ beds were prepared in the spring of each melon production season following a standard winter fallow. Treflan, a postemergence soil-incorporated herbicide, was used in the conventional system, while no herbicide was used in either of the mulch systems. The cover crops were chopped twice using a Buffalo Rolling Stalk Chopper in April 1998 and April 1999, and Goldmaster, an open-pollinated melon variety, was seeded in April 1998 and May 1999. A Ferguson rototiller-type strip-tiller was used in these trials to till and mix the surface soil and cover crop in a 5-inch $(12-\mathrm{cm})$ band. Liquid fertilizer was applied weekly through surface drip tape at a rate of 20 pounds per acre $(22.4 \mathrm{~kg} / \mathrm{ha})$ of nitrogen per week to a total of 160 pounds per acre (179.2 kg/ha). Marketable yields were determined for each melon crop by harvesting the center 2,000 square feet (186 sq $\mathrm{m}$ ) of each treatment plot (table 7).

The standard tillage system produced a slightly higher yield of melons. A number of factors might have contributed to this result. First, because of the large clods that were turned up during strip-tilling, emergence of some melon seedlings was prevented or at least delayed. Second, although identical fertigation rates were used in both the strip-tillage and the standard-tillage systems, early-season melon plant growth and vigor were stunted in the strip-till plots. Finally, because of these delays in growth and development, flowering and fruit set may not have occurred during optimal temperature conditions in the strip-till plots, and this may have resulted, at least partially, in lower productivity. Each of these issues needs to be taken into consideration when trying to use strip-till mulch systems for melons.

Table 7.Melon yields (number of \#9, 12, and 15 melons per acre for 4 harvests each year; means \pm standard error of the mean) produced under strip-till conditions, Five Points, CA, 1998 and 1999

\begin{tabular}{|l|c|c|}
\hline & 1998 & 1999 \\
\hline $\begin{array}{l}\text { Conventional tillage with } \\
\text { winter fallow }\end{array}$ & $12,032 \pm 409$ & $13,339 \pm 314$ \\
\hline $\begin{array}{l}\text { Strip-till with winter rye/vetch } \\
\text { cover crop mulch }\end{array}$ & $11,783 \pm 890$ & $13,056 \pm 1,086$ \\
\hline $\begin{array}{l}\text { Strip-till with winter subclover } \\
\text { cover crop mulch }\end{array}$ & $11,394 \pm 513$ & $12,431 \pm 1,715$ \\
\hline
\end{tabular}

\section{FUTURE TILLAGE SYSTEMS}

Recent surveys of farmers conducted by the UC Agriculture and Natural Resources Conservation Tillage Workgroup, comprised of UC researchers, USDA Natural Resource Conservation Service conservationists, farmers, and other private industry members, revealed that minimum-tillage production systems are becoming increasingly common in annual row crop production not only in the Central and Salinas Valleys, but also in the southern Sacramento Valley and in desert production areas. These systems may reduce production costs by decreasing the number of tillage passes that are used for seedbed preparation. Recent research indicates a direct relationship between the number of tractor passes and the amount of airborne particulate matter emissions (Baker et al. 2002). Minimum tillage may reduce the amount of particulate matter produced and positively contribute to efforts aimed at improving air quality. 
Our current state of knowledge suggests that benefits of minimum tillage can include lower fuel use, reduced labor, higher accumulation of active carbon in surface soils, and less nitrate leaching potential, while the effect on yield is slight over the short term. However, possible drawbacks of minimum tillage may influence growers' decisions to adopt minimum tillage or permanent-bed systems over longer durations. These drawbacks include slightly lower yields, potential disease problems, and a need to compensate for lower crop nitrogen and phosphorus levels by adding additional fertilizer. Despite these problems, the economic returns and environmental benefits of minimum tillage may pay off in the long term even if used intermittently with conventional tillage.

\section{REFERENCES}

Baker, J., R. J. Southard, and J. P. Mitchell. 2002. Agricultural dust production in standard and conservation tillage systems in the San Joaquin Valley. In Proceedings-Conservation tillage 2002: Research and farmer innovation conferences. Davis and Five Points, CA. September 17 and September 19.

Carter, L. M. 1996. Tillage. In S. J. Hake, T. A. Kerby, and K. D. Hake, eds., Cotton production manual. Oakland: University of California Division of Agriculture and Natural Resources Publication 3352. 175-186.

CTIC, 2002. National crop residue management survey. West Lafayette, IN: Conservation Technology Information Center.

Jackson, L. E., I. Ramirez, I. Morales, and S. T. Koike. 2002. Alternative tillage practices for lettuce production. Cal. Ag. 56:35-39.

Jackson, L. E., I. Ramirez, R. Yokota, S. A. Fennimore, S. T. Koike, D. Henderson, W. E. Chaney, F. J. Calderón, and K. Klonsky. 2004. On-farm assessment of organic matter and tillage management on vegetable yield, soil, weeds, pests and economics in California. Agric. Ecosys. and Env. In press.

Karlen, D. L., D. C. Erbach, T. C. Kaspar, T. S. Colvin, E. C. Berry, and D. R. Timmons. 1990. Soil tilth: A review of past perceptions and future needs. Soil Sci. Soc. Am. J. 54:153-161.

Klonsky, K. 1991. Budget planner overview. Davis: University of California, Davis, Department of Agricultural Economics.

Koller, K. 2003. Techniques of soil tillage. In A. E. Titi, ed., Soil tillage in agroecosystems. New York: CRC Press.

Larson, W. E., and G. J. Osborne. 1982. Tillage accomplishments and potential. In P. W. Unger, D. M. Van Doren Jr., F. D. Whisler, and E. L. Skidmore, eds., Predicting tillage effects on soil physical properties and processes. Madison, WI: American Society of Agronomy Special Publication 44.

Reicosky, D. C., W. A. Dugas, and H. A. Torbert. 1997. Tillage-induced soil carbon dioxide loss from different cropping systems. Soil Tillage Res. 41:105-118.

Schlesinger, W. H. 1985. Changes in soil carbon storage and associated properties with disturbance and recovery. In J. R. Trabalha and D. E. Reichle, eds., The changing carbon cycle: A global analysis. New York: Springer-Verlag. 194-220.

Silgram, M., and M. A. Shepherd. 1999. The effects of cultivation on soil nitrogen mineralization. Adv. in Agron. 65:267-311. 


\section{FOR FURTHER INFORMATION}

For more information on the issues discussed in this publication, please visit the UC Conservation Tillage Workgroup's Web site, http://groups.ucanr.org/ucct/.

Visit the ANR Communication Services online catalog at http://anrcatalog.ucdavis.edu. You can also place orders by mail, phone, or FAX, or request a printed catalog of our products from:

University of California

Agriculture and Natural Resources

Communication Services

6701 San Pablo Avenue, 2nd Floor

Oakland, California 94608-1239

Telephone: (800) 994-8849 or (510) 642-2431; FAX: (510) 643-5470

E-mail inquiries: danrcs@ucdavis.edu

An electronic version of this publication is available on the ANR Communication Services Web site at http://anrcatalog.ucdavis.edu.

\section{Publication 8132}

(C) 2004 by the Regents of the University of California, Division of Agriculture and Natural Resources. All rights reserved.

To simplify information, trade names of products have been used. No endorsement of named or illustrated products is intended, nor is criticism implied of similar products that are not mentioned or illustrated.

The University of California prohibits discrimination against or harassment of any person employed by or seeking employment with the University on the basis of race, color, national origin, religion, sex, physical or mental disability, medical condition (cancer-related or genetic characteristics), ancestry, marital status, age, sexual orientation, citizenship, or status as a covered veteran (special disabled veteran, Vietnam-era veteran or any other veteran who served on active duty during a war or in a campaign or expedition for which a campaign badge has been authorized). University Policy is intended to be consistent with the provisions of applicable State and Federal laws.

Inquiries regarding the University's nondiscrimination policies may be directed to the Affirmative Action/Staff Personnel Services Director, University of California, Agriculture and Natural Resources, 300 Lakeside Drive, 6th Floor, Oakland, CA 94612-3550, (510) 987-0096. For a free catalog of other publications, call (800) 994-8849. For help downloading this publication, call (530) 754-5112.

This publication has been anonymously peer reviewed for technical accuracy by University of California scientists and other qualified professionals. This review process was managed by the ANR Associate Editor for Pest Management. 